Polymer-Supported

Synthesis

\title{
C-C Cross-Coupling of Alcohols Catalyzed by $\mathrm{Ag} / \mathrm{Al}_{2} \mathrm{O}_{3}$
}

\section{Key words}

C-C bond formation alcohols $\gamma$-alumina

silver

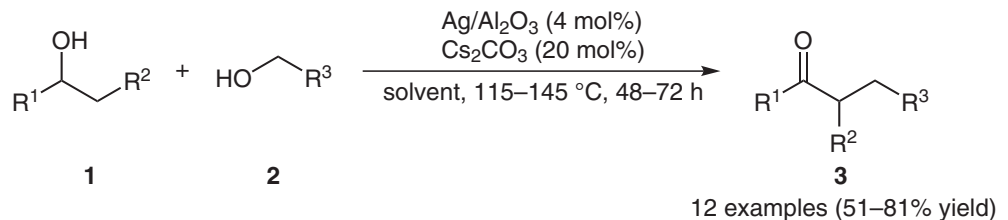<smiles>O=C(CCc1ccccc1)c1ccccc1</smiles>

3a (PhMe, $\left.115^{\circ} \mathrm{C}, 48 \mathrm{~h}, 80 \%\right)$<smiles>O=C(CCc1ccc(F)cc1)c1ccccc1</smiles>

3d (PhMe, $\left.115^{\circ} \mathrm{C}, 48 \mathrm{~h}, 67 \%\right)$<smiles>O=C(CCc1ccco1)c1ccccc1</smiles>

3g (PhMe, $\left.115^{\circ} \mathrm{C}, 48 \mathrm{~h}, 81 \%\right)$<smiles>CCCCCC(=O)c1ccccc1</smiles>

3j (p-xylene, $\left.145^{\circ} \mathrm{C}, 48 \mathrm{~h}, 67 \%\right)$<smiles>COc1ccc(CCC(=O)c2ccccc2)cc1</smiles>

3b (PhMe, $\left.115^{\circ} \mathrm{C}, 48 \mathrm{~h}, 73 \%\right)$<smiles>CC(C)(C)c1ccc(CCC(=O)c2ccccc2)cc1</smiles>

3e (PhMe, $\left.115^{\circ} \mathrm{C}, 48 \mathrm{~h}, 74 \%\right)$<smiles>Cc1ccc(C(=O)CCc2ccccc2)cc1</smiles>

3h (PhMe, $\left.115^{\circ} \mathrm{C}, 48 \mathrm{~h}, 79 \%\right)$<smiles>O=C1c2ccccc2CCC1Cc1ccccc1</smiles>

3k (p-xylene, $\left.145^{\circ} \mathrm{C}, 48 \mathrm{~h}, 65 \%\right)$<smiles>Cc1ccc(CCC(=O)c2ccccc2)cc1</smiles>

3c (PhMe, $\left.115^{\circ} \mathrm{C}, 48 \mathrm{~h}, 72 \%\right)$<smiles>O=C(CCc1cccnc1)c1ccccc1</smiles>

3f (PhMe, $\left.115^{\circ} \mathrm{C}, 48 \mathrm{~h}, 70 \%\right)$<smiles>Cc1ccc(C(=O)CCc2ccco2)cc1</smiles>

3i (PhMe, $115^{\circ} \mathrm{C}, 72$ h, $\left.79 \%\right)$<smiles>CCCCC1CCc2ccccc2C1=O</smiles>

3I (p-xylene, $\left.145^{\circ} \mathrm{C}, 48 \mathrm{~h}, 51 \%\right)$
Significance: $\gamma$-Alumina-supported silver clusters $\left(\mathrm{Ag} / \mathrm{Al}_{2} \mathrm{O}_{3}\right)$ catalyzed the $\mathrm{C}-\mathrm{C}$ bond formation of secondary alcohols $\mathbf{1}$ and primary alcohols $\mathbf{2}$ in the presence of $\mathrm{Cs}_{2} \mathrm{CO}_{3}$ to give the corresponding ketones 3 in $51-81 \%$ yield (12 examples). The catalyst was recovered by filtration and reused twice without significant loss of activity after the reactivation (e.g., formation of $\mathbf{3 a} ; 1^{\text {st }}$ reuse: $77 \%$, $2^{\text {nd }}$ reuse: $\left.78 \%\right)$.
Comment: The authors have previously reported the preparation of $\mathrm{Ag} / \mathrm{Al}_{2} \mathrm{O}_{3}$ and its application to dehydrogenation of alcohols (Chem. Eur. J. 2009, 15, 2341). The authors proposed a reaction pathway for the present coupling as follows: (1) dehydrogenation of $\mathbf{1}$ and $\mathbf{2}$ forming the corresponding ketone and aldehyde along with co-production of $\mathrm{Ag}-\mathrm{H}$; (2) dehydrative cross-aldol reaction giving $\alpha, \beta$-unsaturated ketone; (3) reduction of the $\mathrm{C}=\mathrm{C}$ bond to give $\mathbf{3}$. 